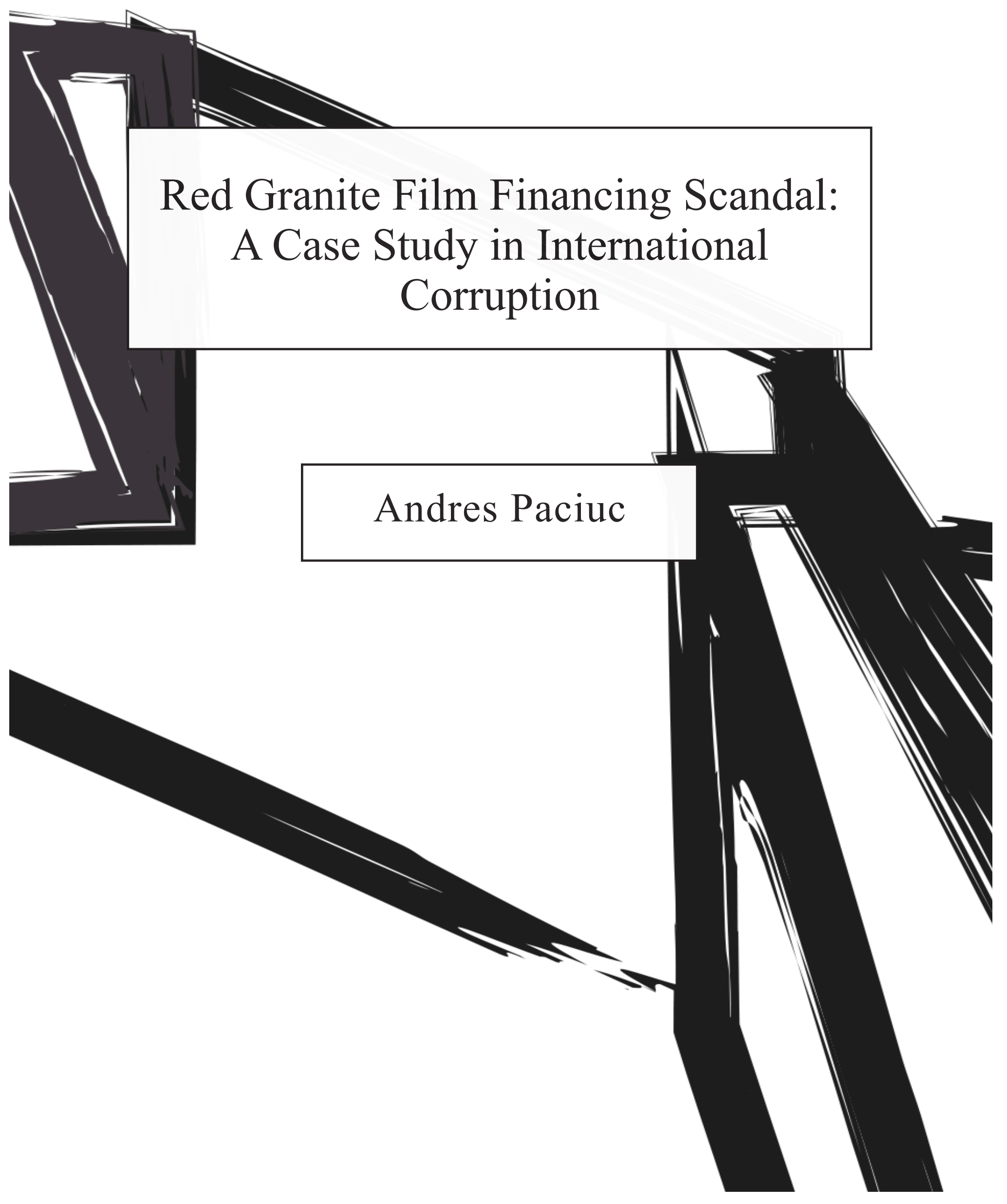





\section{Red Granite Film Financing Scandal: A Case Study in International Corruption}

Andres Paciuc

Abstract: This article investigates international kleptocracy through the lens of one specific case, the Red Granite financing scandal from 2016. Red Granite, a film financing company run by two Malaysian financiers and a businessman from Kentucky, collaborated with Leonardo DiCaprio to create what would become Martin Scorsese's film The Wolf of Wall Street. However, the Department of Justice discovered that the funding for the film may have been illicit. The subsequent embezzlement scandal involved the investigation of stolen funds from the financial fund 1Malaysia Development Berhard, which was owned by the Malaysian government for the purpose of national economic development. The scandal further demonstrates how domestic legal initiatives are necessary to fight the complex networks of global corruption that too often hinder developing countries' economic growth.

Keywords: International Corruption, Film Finance, The United Nations Convention Against Corruption 


\section{Introduction}

The Department of Justice (DOJ) discovered that Martin Scorsese's star-studded film about financial fraud, The Wolf of Wall Street, may have been financed using illicit means. In what the Federal Bureau of Investigation has called the "largest kleptocracy case to date," the Department of Justice sought to recover more than one billion dollars in assets embezzled from Malaysia's 1MDB Fund, which was created by the Malaysian government to boost the country's economic development.[1] The Department of Justice filed a lawsuit against Red Granite, the film's financing company, alleging that they illegally diverted millions of dollars from the $1 \mathrm{MDB}$ fund to finance the Hollywood hit.[2]

This article will use the 1MDB scandal as a case study to demonstrate how domestic legal initiatives are essential in fighting the complex networks of global corruption and money laundering that too often hinder developing countries' economic growth. The article will begin by delving into the details of the Red Granite case, exploring the key players responsible and their connections to the Malaysian government. After reviewing the particularities of the Red Granite case, the article will zoom out to show how The Wolf of Wall Street film financing scandal is merely a drop in the bucket of corruption regarding the 1MDB fund. The complicity of the Swiss and Singaporean banks, multiple foreign governments, and shell companies involved highlights the complex network of global money laundering that facilitates kleptocracy in developing nations. Secondly, the article will explore a major international anti-corruption initiative enacted by the United Nations. While these types of initiatives are wellintentioned, the article will argue that they are not an efficient means to combat global corruption networks due to obstacles of implementation. Finally, the article will propose a more efficient solution to thwarting kleptocrats around the world: implementing domestic, independent anti-corruption initiatives in the countries that can afford to do so. 


\section{Red Granite Case Background}

In July 2016, the DOJ filed a complaint against the producers of The Wolf of Wall Street motion picture, including any rights to profits, royalties, and distribution proceeds owed to Red Granite Pictures Inc., or its affiliates."[3] The United States, the plaintiff of the case, was seeking civil forfeiture of the assets that are traceable to "an international conspiracy to launder money misappropriated from 1Malaysia Development Berhard (1MDB)."'[4] Some of these assets include the future rights to the film, a hotel and several mansions in Beverly Hills, a New York City penthouse, a bombardier jet, and artwork by Van Gogh and Monet.[5] The most recent development from the case occurred in September 2017, when Red Granite announced that it had agreed to reach a settlement in principle with the United States government.[6] However, no details from the settlement have been released because final filing documentations and necessary approvals within the government are still pending.

To understand the key players involved in the scandal and their connections to the embezzlement requires a brief history of how Red Granite Pictures, the once unknown film company, made a name for itself in Hollywood by financing the expensive Wolf of Wall Street. Riza Aziz, the stepson of the Malaysian Prime Minister, Najib Razak, established Red Granite Pictures Inc. in September 2010.[7] Christopher McFarland, a Kentucky businessman with no prior experience in the film industry, is the vice chairman of Red Granite Pictures who helped Aziz with its creation.[8] The two men were introduced by their mutual friend, Jho Low, a "Malaysian financier and confidant of Prime Minister Razak" who became famous for his lavish lifestyle in Los Angeles, California.[9]

At the same time, The Wolf of Wall Street was running into trouble. Leonardo DiCaprio had long been interested in making a film based on the memoirs of Jordan Belfort, the infamous penny stock trader who made a fortune through financial fraud.[10] However, the inappropriate content of the film made the picture an unappealing investment for many major studios. Even though Warner Bros. had acquired the rights to Belfort's memoir in 2007, 
the project stalled at the studio due to its expensive price tag.[11] Low, a friend of DiCaprio's, knew that the actor was looking for a financier and consequently connected him to Red Granite Pictures.

Red Granite was more than willing to invest in the risky project and publicly announced that it would be financing the film at a multi-million-dollar party at the Cannes Film Festival in 2011. However, something was off about Red Granite. McFarland had no prior film industry experience and the company had seemingly come out of nowhere. Regardless, shooting for The Wolf of Wall Street began in August 2012.[12] Throughout the production, DiCaprio, Low, and Aziz maintained a close friendship.

Red Granite's unexpected success may have come from the billions of dollars that the company embezzled from the Malaysian Development Fund. In what Assistant Attorney General Caldwell called "a case where life imitated art," Red Granite Pictures allegedly used millions of dollars from the $1 \mathrm{MDB}$ fund to finance the film.[13] 1Malaysia Development Berhard is a "strategic investment and development company wholly-owned by the Malaysian government, through the Malaysian Ministry of Finance."[14] It was created as a way to spur the country's economic development through foreign direct investment and joint ventures. Despite the fact that Red Granite used hundreds of millions of dollars from the fund, 1MDB and Malaysian taxpayers saw no returns on The Wolf of Wall Street or any of Low, McFarland, or Aziz's extravagant purchases.[15] Ironically, the film was not permitted to play in Malaysia due to local morality laws.[16] Corruption of this sort hurts the nation's most vulnerable, such as Malaysian taxpayers, and benefits the already rich, thus furthering the great economic inequality that exists within developing nations.

\section{The Global Scope of the 1MDB Corruption Scandal}

The Red Granite lawsuit in the United States is not an isolated case involving a few corrupt businessmen. Rather, it is a symptom of an international money-laundering network that facilitates the embezzlement of government funds by the leaders 
of developing countries. By tracing the stolen money's journey from the $1 \mathrm{MDB}$ fund to Red Granite, the article will expose the global mechanisms and networks that enabled this particular case of Malaysian kleptocracy.

In 2012, $1 \mathrm{MDB}$ received 3.5 billion dollars in bond offerings from Goldman Sachs with the stated purpose of using these funds to acquire energy assets. The International Petroleum Investment Company (IPIC), which is a sovereign wealth fund completely owned by the United Arab Emirates, guaranteed these bonds.[17] After the bonds were issued, 1MDB was supposed to transfer 1.3 billion dollars to Aabar Investments PJS, a subsidiary of IPIC, as collateral for the bonds. However, the money never made it to Aabar Investments PJS. Rather, it was transferred to a Swiss bank account operated by a British Virgin Islands company, Aabar Investments PJS Ltd.[18] This almost identically named company was not officially affiliated with IPIC or $1 \mathrm{MDB}$, but was created and named to resemble the legitimate IPIC subsidiary in order to facilitate the fraudulent diversion of funds from 1MDB into the conspirators' pockets.

Days after the fraudulent Aabar Investment PJS Ltd. received the 1.3 billion dollars, the shell company transferred 636 million dollars and 465 million dollars in two separate payments to a Blackstone Account in Singapore, which was owned by one of Low's associates.[19] The money was then diverted from this Singaporean account to the conspirators' accounts. Prime Minister Razak, who is referred to as "Malaysian Official 1" in the DOJ civil lawsuit, received 30 million dollars.[20] 238 million dollars also flowed from the fraudulent Swiss bank account into a Red Granite Capital account in Singapore, owned by Mr. Aziz. The Red Granite Capital account was created by Aziz to fund Red Granite Pictures and The Wolf of Wall Street.[21]

The money successfully moved from the fraudulent Swiss bank account into Red Granite Capital through many intermediaries and shell companies. One of these intermediaries was another British Virgin Islands shell company named Telina Holdings Inc. A loan agreement from Telina Holdings in 2012 proves that approximately 50 million dollars were used to partially finance The Wolf of Wall Street.[22] Red Granite stated that they 
had no reason to believe that the funding for the film was illegal and that they had continued to pay back the film loan to Telina Holdings. However, Telina Holdings had been liquidated at the time that Red Granite claimed to be repaying the film loan, which further suggests Red Granite Picture's use of embezzled funds.[23]

The intricacies of the $1 \mathrm{MDB}$ embezzlement highlights the global mechanisms which enabled the scandal to occur. To merely blame a corrupt Malaysian government for the billions of dollars embezzled would be a myopic view of the issue. As was shown through the embezzled money's journey, the global corruption chain involved multiple shell companies, government officials, and foreign banks. While the DOJ investigation has been unsuccessful in concluding whether Goldman Sachs, Singaporean banks, and other international financial institutions were aware that they were dealing with embezzled money, the government of Singapore banned Tim Leissner, the former chairman of Goldman Sachs' Southeast Asian branch, from entering the country. Regardless of these institutions' knowledge or lack thereof, they still played an integral role in the global money-laundering network.

The ease with which the conspirators embezzled money through various shell companies in financial safe havens like Switzerland, Singapore, and the British Virgin Islands, alongside the bank's lack of oversight and failure to detect the string of fraudulent transactions, attests to the need for a new approach in combating global corruption and money-laundering networks that enables cases like the 1MDB scandal.

\section{International Anti-Corruption Initiatives}

A practical approach to dealing with global corruption and money laundering networks is to tackle the issue on a global scale. International anti-corruption initiatives, like the United Nations Convention Against Corruption, aim to foster collaboration between countries and increase accountability among member parties in the global fight against corruption.

The United Nations Convention Against Corruption (UNCAC) is recognized by most scholars as the most 
comprehensive anti-corruption treaty to date.[24] Thus, it offers a prime example of the strengths and flaws of a global approach to corruption. The UNCAC was signed in Merida, Mexico in 2003 and enacted in 2005.[25] UNCAC stands out among other anti-corruption treaties because it recognizes that corruption is a problem of international interest affecting both developed and developing nations. As of January 2013, 165 nations had ratified UNCAC, which makes it the most global anti-corruption initiative to date.[26] The group of member states that chose to ratify the treaty includes states that had never ratified any other international treaty dealing with corruption, such as the People's Republic of China.[27] The extensive support for the initiative is a testament to its truly global scope. UNCAC's purpose is threefold. First, it aims "to promote and strengthen measures to prevent and combat corruption more effectively." Second, it aims to "promote, facilitate, and support international cooperation in the prevention of and fight against corruption." Third, it strives to "promote integrity, accountability, and proper management of public affairs and public property."[28] UNCAC addresses these aforementioned goals through four main sections.[29]

Firstly, UNCAC's Preventative Measures section details the steps that member states need to take in order to minimize the incidence of corruption. The UNCAC stands out in this regard because its binding, preventative laws apply to both the public and private sectors. [30] In the sphere of the public sector, the treaty requires member states to take the necessary steps to ensure the absence of corrupt influence. For example, it requires member states to institute independent anti-corruption bodies capable of implementing and coordinating relevant policies.[31] The treaty also requires member states to establish appropriate procurement bodies, intended to strengthen the integrity of their judiciary and promote the active participation of civil society.[32] The treaty also requires member states to take preventative anti-corruption measures in the realm of the private sector. For example, it requires states to monitor banks through a comprehensive regulatory regime in order to prevent money laundering.[33] UNCAC deals extensively with the banking sector, requiring that member states ensure that bank secrecy laws can be overcome during corruption 
investigations. [34]

The International Collaboration section of the treaty emphasizes the global scope of corruption and the importance of member states' cooperation in tackling the problem. The treaty requires member states to offer each other legal assistance when dealing with crimes that violate UNCAC's laws.[35] While it makes cross-border cooperation in criminal matters mandatory, the treaty only recommends multinational cooperation in civil and administrative issues.[36] The Criminalization section of the treaty criminalizes corruption in a broader context. UNCAC's comprehensive definition of corruption criminalizes trading in influence, bribery, embezzlement, abuse of functions, illicit enrichment, obstruction of justice, and money laundering, among other offenses.[37] UNCAC redefines "intent" in its treaty.[38] While some domestic legal systems require obvious intent in corruption charges, the UNCAC softens the burden of proof. By allowing intent to be derived from inferential evidence, the treaty makes it easier to prove the offender's intent and thus should help the UNCAC prosecute treaty violators more effectively.[39]

\section{Issues with the United Nations Convention Against Corruption}

There is no doubt that The United Nations Convention Against Corruption is global, and well-intentioned. Its extensive laws regarding asset recovery, preventative measures, international collaboration, and criminalization are a significant step in the global fight against corruption. However, the treaty falls short of accomplishing its goal. There is a disconnect between what is said on paper and what is actually done by member states. While the UNCAC is the most comprehensive existing international anti-corruption initiative to date, it still suffers from unfixable inefficiency issues that are to be expected of a global initiative charged with fighting secretive and large-scale criminal behavior.

As exemplified by the United Nations Convention Against Corruption, international anti-corruption initiatives are inefficient and impractical means of curbing corrupt practices. The issues that plague the UNCAC can be categorized into two main groups: direct compliance problems and indirect compliance 
problems.[40] Direct compliance issues are those that are internal to the treaty. For example, these issues arise from the treaty's language, its compliance monitoring mechanisms, and its lack of transparency and impartiality.[41] On the other hand, indirect compliance issues are external factors that interfere with members' compliance to the treaty.[42] Some of these obstacles include collective action costs, good governance, and the secretive nature of corruption. Considering that indirect compliance issues are not products of the treaty, they are extremely difficult, if not impossible, to fix.

A prominent direct compliance problem is the UNCAC's ambiguous language. The language in many of the treaty's articles can lend itself to multiple interpretations and thus reduce compliance of member states. As stated above, one of the treaty's preventative public-sector requirements is that members institute independent anti-corruption regulatory bodies. The specific wording of the article reads as follows: "Each state party shall, in accordance with the fundamental principles of its legal system, ensure the existence of a body that prevents corruption by such means as..."[43] With its inclusion of the word "shall," this phrase appears to be clear and legally binding. However, the phrase "in accordance with the fundamental principles of its legal system" as a qualifying clause has the potential to reduce compliance.[44] This type of language could be interpreted differently by various member states, thereby leading to both intentional and permissive interpretations of the law.[45]

It is difficult to strike a balance between the language's vagueness and specificity. Language that is too vague and accommodating is likely to result in non-compliance from member states. On the contrary, language that is too specific and compulsory may lead states to fear sovereignty infringement and thus may also result in non-compliance.[46] The divergent interpretations of the facilitation payments section by the United States and the United Kingdom are testament to the treaty's different kinds of interpretations.[47] The U.S. has interpreted the treaty's language in a way that allows facilitation payments. This is due to the fact that the U.S.' Foreign Corrupt Practices Act allows exceptions for facilitation payments. The U.K., on 
the other hand, has interpreted the UNCAC's language as to prohibit facilitation payments. This interpretation of UNCAC is in accordance with the U.K.'s Anti-Terrorism Act.[48] The treaty's vague language allows for misinterpretations that are based on each state's legal idiosyncrasies, which could lead to disagreement among member states. Another problem with the treaty's language arises with the definition of corruption itself. There is a lack of consensus among member states regarding the legal definition of corruption.[49] Should it include smallscale bribery and facilitation payments that are characteristic of developing countries' bureaucracies? Or should it only include large-scale corrupt practices like embezzlement and money laundering? Considering that scholars disagree on such issues, it is no surprise that member states disagree on the definition of corruption.[50] States have different cultures surrounding the topic of corruption as well as legal definitions for it. The UNCAC tries to deal with the definitional problem by providing a broad enough definition that can be adapted by as many member states as possible.[51] While this attempt is well-intentioned and accommodating, in practice, it leads to too many issues of noncompliance by reducing its ability to be legally-binding.

One of the UNCAC's most salient direct compliance problems is its lax monitoring system. In 2009, UNCAC established its official Review Mechanism, which is far from groundbreaking.[52] The Review Mechanism works as a monitoring cycle in which member states fill out a selfassessment checklist and then are peer-reviewed by two other member states. [53] The checklist consists of criteria that pertain to the treaty's different sections and the member state is asked to evaluate its own performance. This self-assessment checklist is then used as the basis for the peer review. Out of the two member states that are tasked with the review, one must be within the same geographical area as the state under review. The reviewers from the two member states consist of government experts and are selected randomly. The peer review does not consist of any country visits or other forms of tangible assessments. Rather, the whole procedure is a desk review.[54]

There are obvious problems that arise from the UNCAC's 
lenient review mechanism. Due to reputation and diplomatic concerns, the member state that is under review has an incentive to omit the truth or understate the problem. The inevitable conflicts of interest that arise from self-assessment greatly delegitimize the treaty's review mechanism. The lack of country visits also makes accurate assessments difficult for the two reviewing member states. Considering that corruption is a crime that thrives in secrecy, it is unlikely that reviewers will get an accurate picture of the country's corruption without directly visiting it and auditing its key institutions.

Member states opposed more stringent monitoring laws because of fear that such laws would lead to violations of their sovereignty.[55] This is a characteristic problem of the treaty; it is difficult to preserve member state's sovereignty while still implementing mechanisms capable of effectively curbing corruption. Thus, the UNCAC takes a cooperative approach rather than a strict and punitive one. Its monitoring system serves as an instrument for international cooperation. While facilitating international cooperation is definitely a useful characteristic of the treaty, it lacks enforcement mechanisms. There are no military or monetary consequences for violating the treaty's laws; UNCAC does not penalize its members for noncompliance.[56] Aside from protecting their reputation, member states have no tangible reason to abide by the treaty's laws. The fact that Malaysia ratified the UNCAC and was still involved in the 1MDB scandal is testament to the lack of tangible incentive to obey the treaty's laws.

One of the most prominent flaws of the treaty's monitoring mechanism is its lack of transparency. The country reports are confidential and unavailable to the public.[57] The lack of participation from civil society and the private sector in monitoring makes it difficult to accurately evaluate a member state's corruption. The failure to do so also undermines the principles of transparency and impartiality which the treaty so fervently espouses and requires from its member states.

There are many issues of indirect compliance that make the UNCAC even harder to enforce. Issues of indirect compliance are particularly difficult to resolve because they concern factors 
that are external to the UNCAC itself. Thus, amending the treaty or changing it substantially is a futile endeavor when it comes to these types of issues. Collective action costs are a characteristic problem of international treaties. While every member state would benefit from implementing and enforcing the UNCAC, it is hard to convince member states to diminish their territorial sovereignty.[58] Member states that highly value their territorial integrity have a strong incentive to defect, which is partly responsible for the lack of enforcement. Furthermore, there are also issues involving the high quantity of member states in the UNCAC. At first glance, having as many member states as possible seems like a logical goal. As more countries join the UNCAC, other countries will feel more compelled to join and fight corruption.[59] However, this view ignores a substantial portion of the problem. As more parties join an agreement, finding common ground regarding the definition of corruption, the monitoring mechanism and other controversial aspects of the treaty become extremely difficult.[60] Diverging opinions amongst multiple parties can greatly delay the decision-making process as they struggle to compromise and find common ground, which in turn slows a much-needed compliance response by the parties who are most affected by corruption. Even though the treaty was enacted in 2005, a monitoring mechanism was not effectively negotiated until 2009.[61] These are the typical problems that arise from such large-scale international treaties.

The most pervasive indirect compliance issue is that member states' social, economic, and political conditions often prevent the states' enforcement of the treaty. A useful way to look at the socio-political and economic issues that can inhibit treaty compliance is in terms of "good governance."[62] Its broad and accepted definition is "the proper functioning of the governmental machinery."[63] Efficient and effective domestic institutions are a key component of good governance; the presence or lack of strong domestic institutions can influence a state's likelihood of enforcing the UNCAC. The media, the judiciary, and political parties that are free to operate independent of the executive branch of government are all examples of strong domestic institutions. [64] These types of institutions are essential to both 
the domestic rule of law and the enforcement of international law.[65] When international treaties like the UNCAC have lax or nonexistent enforcement mechanisms, the responsibility falls on the member states' domestic institutions to ensure that the treaty is effectively implemented.[66] According to Hathaway's Integrated Theory of International Law, weak and developing democracies are less likely to abide by international law if they lack strong and independent domestic institutions.[67] If there is no external enforcement of the treaty by transnational bodies and the member states lack key components of good governance, it is unlikely that these states will abide by the international treaty. This further explains why the UNCAC is a recipe for noncompliance. Since the UNCAC solely focuses on a collaborative approach and lacks punitive and tangible enforcement mechanisms, the member states lacking strong domestic institutions are the ones that are the least likely to comply with the treaty. Weak domestic institutions are inextricably linked with corruption. Thus, the member states with the most corruption are the ones that are the least likely to enforce the UNCAC. The opposite is true in the case of strong democracies. Member states that have strong domestic institutions are more likely to abide by international law, regardless of whether the treaty is enforced by transnational bodies.[68]

Ratifying an international treaty and actually enforcing it are entirely different tasks. Evidence from different countries' ratification of the United Nations Convention Against Torture suggests that states are motivated to ratify an international treaty even if they don't plan to enforce it.[69] For example, non-democratic nations with the worst records of torture were more likely to commit to the Convention Against Torture than those countries where torture is less prevalent.[70] The countries with the worst ratings of torture have an incentive to improve their reputation in the international sphere, which is a plausible reason why these countries committed to the anti-torture treaty at higher rates than democratic nations. However, the fact that these high-torture states ratified the treaty doesn't mean that they have actually stuck to the treaty's core principles. A similar situation also applies to the enforcement of the UNCAC. 
Countries like Mexico, Malaysia, Venezuela, and Libya have ratified the UNCAC. These member states, however, all have terrible scores on the 2016 Corruption Perceptions Index.[71] Thus, it is a possibility that member states lacking the necessary independent and regulatory domestic institutions to monitor kleptocracy and curb corruption are inclined to ratify the treaty without enforcing it. By ratifying the UNCAC, countries with weak domestic institutions can improve their reputation in the international community, leading to collateral benefits like an increase in foreign direct investment. The fact that many of the member states which ratified the UNCAC in 2005 have not experienced an improvement in their Corruption Perception Index from 2005 to 2016 highlights the gap between state's ratification and enforcement of the treaty.[72]

Even if member states are willing and committed to enforce the UNCAC, many are physically unable to do so due to a lack of resources and manpower. Fighting corruption is costly. It often requires a strong and independent police force, good knowledge of the international banking system, effective financial task forces, and a strong judiciary capable of persecuting corrupt offenses.[73] The effects of the lack of resources to combat corruption are exemplified by Nigeria's inability to effectively uncover and persecute money-laundering offenses.[74] Most money laundering crimes are committed and hidden using advanced finance computers and complex software. As of 2011, the Nigerian Supreme Court had yet to amend and update its Evidence Act to include computer-generated bank statements.[75] The lack of legal and economic resources can thus impede a state from effectively adapting to the constantly evolving landscape of corruption.

An indirect compliance issue that is often overlooked when examining the UNCAC is the presence of corrupt leaders. By definition, a kleptocracy is a government run by thieves.[76] How can international anti-corruption initiatives be effectively enforced when corruption is capable of infecting high levels of government? As stated earlier, the DOJ lawsuit alleges that Prime Minister Najib Razak received 681 million dollars from a Saudi Arabian shell company involved in the 1MDB scandal. However, 
Malaysia's attorney general recently cleared the Prime Minister of any wrongdoing. According to the attorney general's decision, the 681 million dollars were a legal gift from Saudi Arabia.[77] Malaysia's constitution prohibits the attorney general's decision from being overturned, which legally and effectively ends the prospects of any further domestic investigations into the Prime Minister's potential involvement in the 1MDB scandal.[78] While it is inconclusive whether the Prime Minister and other high level officials were involved in the scandal, the country's legal system has put the case to rest. The lack of strong, independent domestic institutions makes international anti-corruption treaties extremely hard to enforce.

While global anti-corruption initiatives like the UNCAC effectively condemn corruption in the international sphere, they are essentially futile when it comes to dealing with complex money laundering networks like that of $1 \mathrm{MDB}$. If one looks closely at how the 1MDB scandal was exposed, it wasn't because of the UNCAC or other international anti-corruption initiatives. Rather, the global corruption chain was exposed through the specialized efforts of countries like the United States, Singapore, and Switzerland. The UNCAC's futility in pragmatically detecting and stopping the $1 \mathrm{MDB}$ case suggests that a new approach is needed to combat international corruption networks.

\section{Policy Proposal}

While the UNCAC's direct compliance issues can be improved by revising the treaty's wording, indirect compliance issues are practically impossible to resolve because they are external to the UNCAC. If the UNCAC - the most comprehensive and widely accepted international anti-corruption initiative - still suffers from so many implementation and enforcement flaws, can anything be done to combat the global corruption networks that enabled the 1 MDB scandal? This section of the article will briefly propose an alternative solution to fighting corruption through global-initiatives like the UNCAC: implementing localized anti-corruption initiatives amongst the countries that have the resources to do so, with an emphasis on recovering the stolen 
assets and reinvesting them into developing countries.

While poorer countries don't have enough resources to efficiently institute strong and independent anti-corruption bodies, wealthy and developed countries are more than capable of doing so. Developed countries have the legal, economic, and political resources required to combat corruption through domestic initiatives. There are many advantages to combating global corruption through a domestic approach rather than an international approach. Using a domestic approach, countries don't have to worry about the collective action costs and the differing opinions that are intrinsic to international initiatives. Each state can institute policies that are in accordance with its own legal and cultural idiosyncrasies without having to go through the long bureaucratic process of compromising and finding common ground with other member states. An individualized and domestic approach also avoids sovereignty issues that too often make international initiatives unenforceable. Domestic initiatives allow states to completely retain their sovereignty while more effectively fighting global corruption.

Developed countries like the U.S., the U.K., Singapore, and Switzerland have a responsibility to fight corruption within their borders. A substantial portion of the world's corruption capital flows are laundered through countries with lax financial regulations.[79] As was seen in the $1 \mathrm{MDB}$ scandal, tax havens like Switzerland, the British Virgin Islands, and Singapore enabled the embezzlement of billions of dollars from the Malaysian sovereign wealth fund. Furthermore, most money stolen by kleptocrats, like Low and Aziz, is spent in highly developed nations and cities: Beverly Hills, Cannes, New York City, London, and Las Vegas.[80] This gives developed countries a unique opportunity to fight global corruption. Not only do they have the resources necessary to create efficient anti-corruption bodies and monitoring mechanisms, but they are also capable of breaking the global corruption chain and money laundering. If kleptocrats' assets are consistently seized in developed nations, it is likely to reduce their willingness to engage in corrupt behavior. By implementing stricter banking regulations, tax havens can disrupt the global chain of money laundering by reducing the means 
through which corrupt leaders and businessmen can transfer and spend embezzled money. Through stipulating the seizure of illegal money that is laundered within their borders, domestic initiatives in developed nations would avoid impinging on other nations' sovereignty. While it is unlikely that the U.S. could successfully persecute Aziz or Low, seizing their stolen assets sends a clear political message to Malaysia while simultaneously breaking the global corruption chain.

It's in the best interest of developed nations to go after money laundering that occurs within their borders. While a moral obligation to the numerous victims of corruption may not be enough to incentivize developed nations to implement domestic anti-corruption initiatives, the direct security threats and economic losses to developed nations that arise from global corruption should serve as a strong incentive for them to combat corruption. The World Economic Forum estimates that the cost of corruption equals five percent of the world's total GDP; this means that around 2.6 trillion dollars are lost to corruption every year.[81] Also, there are many studies that suggest that corruption and money laundering in developing nations pose a security threat to the developed West.[82] For example, corruption in Afghanistan not only impedes its citizens from receiving basic public services, but it has also led to the resurgence and strengthening of the Taliban.[83]

The domestic anti-corruption initiatives in Singapore serve as evidence that, when executed correctly, these types of institutional bodies are effective in curbing corruption. Singapore's enactment of the Prevention of Corruption Act in 1959 and the institution of the Corrupt Practices Investigation Bureau played an essential role in the state's fight against corruption, helping it achieve its status as a strong economic and political power today. Since 1960, the CPIB has pursued a comprehensive anticorruption strategy by removing both the opportunities and the incentives for corruption. [84] The CPIB ensures compliance with the POCA and has three main branches: the Investigative Branch, the Data Management and Support Branch, and the Administrative Branch.[85] Part of what makes the CPIB so successful is that it treats corruption as a serious offense, raising the penalty for 
corruption both in terms of prison time and financial fines.[86] For example, the prison time for corruption was raised to five years, the minimum fine for an illegal gratification payment was raised to $\$ 10,000$, and a person found guilty of accepting a bribe had to pay the amount of the bribe in addition to other penalties imposed by the court. Working independently from the police force, CPIB officers have the authority to arrest those found guilty of corruption according to the Bureau's investigations. [87] The Bureau also has the power to investigate the bank accounts of any persons who are suspected of corruption, thus serving as an effective check on high-level bureaucrats and government officials.[88] Lastly, the Prevention of Corruption Act is easily amenable, giving it the necessary adaptive qualities required to effectively fight corruption. [89]

The 1MDB scandal demonstrates the global nature and impact of kleptocrats. Those who were connected to the Malaysian Prime Minister allegedly exploited a sovereign wealth fund that was intended to help the country's economic development. The embezzled money was laundered and ostentatiously spent in various developed nations across the globe. While international anti-corruption initiatives like the UNCAC treaty highlight the importance of international collaboration in fighting corruption, its numerous noncompliance issues make it nearly impossible to enforce. The UNCAC is thus more emblematic of the need to curb global corruption rather than a tangible way to reduce corruption and hold kleptocrats accountable. A more effective strategy would be to institute domestic anti-corruption bodies in the nations that can politically, economically, and legally afford to do so. Considering the high economic and security costs that arise from corrupt practices, developed nations have an incentive to institute strong and independent domestic anticorruption initiatives. While more research is necessary, current domestic anti-corruption initiatives are promising. For example, a substantial amount of the embezzled 1MDB money was laundered and stored in Singapore.

Singapore's recent conviction of a banker named Low involved in the scandal and subsequent seizure of his private jet indicate success of Singapore's domestic anti-corruption 
efforts. Developed nations where stolen money tends to circulate should follow Singapore's example and implement similar anticorruption policies. Domestic anti-corruption initiatives are an effective way to keep foreign kleptocrats accountable by limiting the pathways through which the stolen money is laundered and spent, hitting the kleptocratic leaders where it hurts them the most: their pockets. 


\section{Notes:}

1 Federal Bureau of Investigation, International Corruption: U.S. Seeks to Recover \$1 Billion in Largest Kleptocracy Case to Date (July 20, 2016), https://www.fbi.gov/news/stories/ us-seeks-to-recover-1-billion-in-largest-kleptocracy-case-todate.

2 Alex Ritman, 'Wolf of Wall Street' Corruption Scandal: The Assets, Hollywood Reporter (July 21, 2016), http://www. hollywoodreporter.com/lists/wolf-wall-street-corruptionscandal-913330/item/bo mbardier-global-5000-wolfwall-913309.

3 Department of Justice Complaint, United States v. "The Wolf of Wall Street" Motion Picture, 1, 2 No. CV 16-16-5362 (C.D. Cal. July 20, 2016).

4 Id.

5 Alex Ritman, 'Wolf of Wall Street' Corruption Scandal: The Assets, Hollywood Reporter (July 21, 2016), http://www. hollywoodreporter.com/lists/wolf-wall-street-corruptionscandal-913330/item/time-warner-center-penthousewolf-913318.

6 https://www.reuters.com/article/legal-us-malaysia-scandalredgranite/the-wolf-of-wall-street-producer-settles-us-suitlinked-to-malaysian-fund-idUSKCN1BT17I

7 Alex Ritman, Follow the Money: 'The Wolf of Wall Street' Corruption Timeline, Hollywood Reporter (July 22, 2016), http://www.hollywoodreporter.com/news/follow-moneywolf-wall-street-913395.

8 Bradley Hope, John R. Emshwiller \& Ben Fritz, The Secret Money Behind 'The Wolf of Wall Street', Wall Street Journal (April 1, 2016), http://www.wsj.com/articlesmalaysias- 
$1 \mathrm{mdb}-\mathrm{the}-\mathrm{sec}$ et-money-behind-the-wolf-of-wallstreet-1459531987.

9 Id.

10 Id.

11 Id.

12 Id.

13 Leslie R. Caldwell, Speaker, Department of Justice, Caldwell Remark on Kleptocracy Enforcement (July 20, 2016), https://www.justice.gov/opa/speech/assistant-attorneygeneral-leslie-r-caldwell-delivers-remarks-press-conferenceannouncing.

14 "The Wolf of Wall Street" Motion Picture, No. CV 16-1653621 at 5 .

15 Id., at 6.

16 Id.

17 Id., at 39.

18 Id., at 7.

19 Id., at 40.

20 Id., at 11.

21 Bradley Hope, John R. Emshwiller \& Ben Fritz, The Secret Money Behind 'The Wolf of Wall Street', Wall Street Journal (April 1, 2016), http://www.wsj.com/articles/ malaysias-1 mdb-the-secret-money-behind-the-wolf-of-wallstreet-1459531987. 
22 Id.

23 Id.

24 Mark V. Vlasic \& Jenae N. Noell, Fighting Corruption to Improve Global Security: An Analysis of International Asset Recovery Systems, 5 Yale J. Int'l Affairs 106, 110 (Jul. 20, 2010).

25 Jan Wouters, Cedric Ryngaert \& Ann Sofie Cloots, The International Legal Framework Against Corruption: Achievements and Challenges, 14 Melb. J. Int'1 L. 205, 216 (2013).

$26 \mathrm{Id}$.

27 Ophelie Brunelle-Quraishi, Assessing the Relevancy and Efficacy of the United Nations Convention Against Corruption: A Comparative Analysis, 2 Notre Dame J. Int'l \& Comp. L. 101, 106 (2011).

28 Id., at 107.

29 Id.

$30 \mathrm{Id}$.

31 Id.

32 Jan Wouters, Cedric Ryngaert \& Ann Sofie Cloots, The International Legal Framework Against Corruption: Achievements and Challenges, 14 Melb. J. Int'1 L. 205, 218 (2013).

33 Id., at 218.

34 Jan Wouters, Cedric Ryngaert \& Ann Sofie Cloots, The International Legal Framework Against Corruption: 
Achievements and Challenges, 14 Melb. J. Int'1 L. 205, 219 (2013).

35 Id., at 218.

36 Id., at 219.

37 Ophelie Brunelle-Quraishi, Assessing the Relevancy and Efficacy of the United Nations Convention Against Corruption: A Comparative Analysis, 2 Notre Dame J. Int'l \& Comp. L. 101, 110 (2011).

38 Id., at 116.

39 Ophelie Brunelle-Quraishi, Assessing the Relevancy and Efficacy of the United Nations Convention Against Corruption: A Comparative Analysis, 2 Notre Dame J. Int'l \& Comp. L. 101, 116 (2011).

40 Id., at 128.

41 Id., at 129.

42 Id.

43 UN General Assembly, United Nations Convention Against Corruption, Article 28 (31 Oct. 2003), https://www.unodc.org/ documents/treaties/UNCAC/Publications/Convention/0850026_E.pdf.

44 Ophelie Brunelle-Quraishi, Assessing the Relevancy and Efficacy of the United Nations Convention Against Corruption: A Comparative Analysis, 2 Notre Dame J. Int'l \& Comp. L. 101, 108 (2011).

45 Id.

46 Id., at 132. 
47 Id., at 131.

$48 \mathrm{Id}$.

49 Id., at 130

50 Id., at 131

51 Id.

52 Jan Wouters, Cedric Ryngaert \& Ann Sofie Cloots, The International Legal Framework Against Corruption: Achievements and Challenges, 14 Melb. J. Int'1 L. 205, 220 (2013).

53 Id.

54 Id.

55 Ophelie Brunelle-Quraishi, Assessing the Relevancy and Efficacy of the United Nations Convention Against Corruption: A Comparative Analysis, 2 Notre Dame J. Int'1 \& Comp. L. 101, 135 (2011).

56 Id., at 140.

57 Id., at 138.

58 Id., at 126.

59 Id., at 127.

60 Id., at 128.

$61 \mathrm{Id}$.

62 Id., at 144. 
$63 \mathrm{Id}$.

64 Oona A. Hathaway, Between Power and Principle: An Integrated Theory of International Law, 72 University of Chicago L. Rev. 469, 520 (2005).

$65 \mathrm{Id}$.

66 Id.

67 Id.

68 Id.

69 Id., at 521.

70 Id.

71 Transparency International, Corruption Perceptions Index 2016 (Jan. 25, 2017), http://www.transparency.org/news/ feature/corruption_perceptions_index_2016.

72 Id.

73 Mark V. Vlasic \& Jenae N. Noell, Fighting Corruption to Improve Global Security: An Analysis of International Asset Recovery Systems, 5 Yale J. Int'1 Affairs 106, 113 (Jul. 20, 2010).

74 Ophelie Brunelle-Quraishi, Assessing the Relevancy and Efficacy of the United Nations Convention Against Corruption: A Comparative Analysis, 2 Notre Dame J. Int'l \& Comp. L. 101, 147 (2011).

75 Id., at 148.

76 Jennifer M. Hartman, Government by Thieves: Revealing the Monsters Behind the Kleptocratic Masks, 24 Syracuse J. Int'1 
L. \& Com. 157 (1997).

77 Oliver Holmes, Decision to Clear Malaysian Prime Minister 'Impossible' to Overturn (Jan. 28, 2016), https://www. theguardian.com/world/2016/jan/28/malaysia-najib-razaksaudi-royal-family-bank-transfer.

78 Id.

79 Mara V. J. Senn \& Giselle K. Fuentes, International Asset Tracing: The Struggle for Transparency Abroad, 28 Crim. Just. 18, 21 (2013).

80 Jennifer M. Hartman, Government by Thieves: Revealing the Monsters Behind the Kleptocratic Masks, 24 Syracuse J. Int'1 L. \& Com. 157, 160 (1997).

81 CleanGovBiz, The Rationale for Fighting Corruption, OECD (2014), https://www.oecd.org/cleangovbiz/49693613.pdf page 2

82 Mark V. Vlasic \& Jenae N. Noell, Fighting Corruption to Improve Global Security: An Analysis of International Asset Recovery Systems, 5 Yale J. Int'l Affairs 106, 108 (Jul. 20, 2010).

83 Id.

84 Id., at 395.

85 Id., at 397.

86 Id., at 395.

87 Id.

88 Id.

89 Id., at 396. 
